\title{
Boundaries of Displacement: Belonging and Return among Forcibly Displaced Young Georgians from Abkhazia
}

\author{
Minna Lundgren \\ Östersund: Mittuniversitetet 2016 \\ 168 sider. ISBN 9789188025807
}

Omtalt af Katrine Bendtsen Gotfredsen [PhD, lektor i Kaukasusstudier, Malmö universitet, katrine.gotfredsen@mau.se]

Mere end 200.000 mennesker lever i dag som internt fordrevne i Georgien som en følge af de interne væbnede konflikter i Abkhasien og Sydossetien. Langt størstedelen flygtede på grund af kampene i Abkhasien i 1990'erne og bor nu på den anden side af, hvad der må betegnes som en de facto-statsgrense imellem Abkhazien og Georgien. I Boundaries of Displacement undersøger Minna Lundgren betydningen af denne grænse, og grænseskabning i bredere forstand, for, hvordan unge eksilgeorgiere fra Abkhasien forstår og praktiserer "hjemland", "tilhørsforhold " og »tilbagevenden".

Den artikelbaserede ph.d.-afhandling indledes med en sammenfattende redegørelse efterfulgt af fire videnskabelige artikler. I den første af disse artikler, Crossing the Border - An Intergenerational Study of Belonging and Temporary Return among IDPs from Abkhazia, søger Lundgren svar på, hvilke faktorer der motiverer eksilgeorgiere til at krydse grænsen til Abkhasien, samt hvad disse bevægelser betyder for deres forståelse af at høre hjemme. Den primære motiverende faktor, viser artiklen, er et ønske om at bibeholde en kontinuitet i tilhørsforholdet til Abkhasien. Internt fordrevne i Georgien lever i en slags "udstrakt midlertidighed", en venten på at vende tilbage til tingenes rette tilstand, hvor få føler, at de faktisk har hjemme, der hvor de bor. Så længe en permanent tilbagevenden ikke er mulig, bliver de periodiske besøg en måde hvorpå man kan opretholde fornemmelsen af stadig at høre til et sted.

Dette spændingsforhold imellem sted, hjem og tilhørsforhold forfølges yderligere i den anden artikel, Avlägsen tillhörighet: Om skapande och upprätthållande av platstillhörighet bland georgiske internflygtninge från Abkhazien. Her belyses især, hvordan et sådant følelsesmæssigt og konkret tilhørsforhold til Abkhasien som hjem og hjemland 
bibeholdes, og i nogle unges tilfælde decideret skabes, på trods af begrænset eller ingen kontakt over længere tid. I sine skildringer af oplevelsen af hjem og tilhørsforhold, og kontrasten imellem faktisk erfaring og politiske og sociale påvirkninger, knytter de to artikler an til mere overordnede spørgsmål om, hvad "hjem" og "hjemland" er, og ikke mindst hvordan disse kategorier og følelser skabes og vedligeholdes af personlige erfaringer i samspil med overleverede minder, sociale relationer og politiske diskurser.

I artiklen Riskscapes: Strategies and Practices Along the Georgian-Abkhazian Boundary Line and Inside Abkhazia anskues spørgsmålet om de facto-grensen og forsøget blandt de internt fordrevne på at bibeholde en tilknytning og kontakt til Abkhasien fra en anden vinkel. Baseret på en håndfuld interviews med unge georgiere undersøges de strategier, de unge benytter for at krydse grænsen - lovligt eller ulovligt - og de mangeartede risici der er forbundet med deres færden i grænselandet. Den væsentlige pointe er her, at oplevelsen af risici, og de unges strategier til at overkomme dem, er foranderlige og konfigureres i relation til identitetsskabende kategorier som køn, alder og etnicitet.

I afhandlingens sidste artikel, Place Matters: Return Intentions among Forcibly Displaced Young Georgians from Abkhazia Living in Tbilisi and Zugdidi, undersøges relationen imellem et antal geografiske, sociale og økonomiske faktorer og unge eksilgeorgieres intentioner om at vende tilbage til et permanent liv i Abkhasien. Det viser sig her, at procentdelen af unge, der ønsker at flytte permanent tilbage, er højere blandt dem, som ikke har haft jævnlig kontakt og tilgang til Abkhasien, hvorimod dem, som bor tættere på og har en vis grad af adgang til tidligere hjem eller nære relationer i Abkhasien, i mindre grad ønsker en sådan permanent tilbagevenden. Dette afspejler et interessant spændingsforhold, som på mange måder gennemsyrer afhandlingen som helhed, nemlig imellem Abkhasien som et mytologisk hjemland skabt igennem kollektive nostalgiske minder og politiske diskurser og Abkhasien som et konkret sted i nutiden, der nok indebærer positive erfaringer, men også en høj grad af usikkerhed, risici og kontinuerlige udfordringer. Abkhasien som myte og forventning synes mere attraktiv end Abkhasien som realitet.

Igennem artiklerne giver Lundgren os indblik i den kompleksitet, der er på spil i unge georgieres forståelse af og tilhørsforhold til, hvad de - af samfundet, deres forældre og i høj grad sig selv - forventes at opfatte som deres sande hjemland. Netop på grund af denne åbenbare kompleksitet ville det også have været interessant at se nogle af de individuelle historier udfoldet yderligere til mere hele og kontekstualiserede portrætter af de unge mennesker, hvis bevægelser, motivationer og intentioner beskrives igennem afhandlingen. Dette gælder i særdeleshed i forhold til beskrivelsen og analysen af de unges erfaringer og oplevelser af hjem- og grænseland, og de specifikke usikkerheder og risici der knytter an til deres køn, alder, etnicitet og familiebaggrund i mødet med nationale idealer og politiske diskurser. Dette har muligvis været svært at skrive frem i det artikelbaserede format, hvor formen på den enkelte artikel er mere fastlåst end i den klassiske monografi. Formatet bidrager også 
til, at afhandlingen som læseoplevelse byder på en del gentagelser - særligt af den empiriske baggrund, men også i nogen grad af diskussionerne af centrale analytiske optikker som grænser, hjem(land), tilhørsforhold og relationen imellem stedslig og tidslig kontinuitet.

Som helhed giver afhandlingen ikke desto mindre et nyt og interessant perspektiv på situationen for internt fordrevne unge fra Abkhasien i Georgien. Den udgør et bidrag til vores viden om et felt, der er yderst politiseret og igen og igen viser sig vanskeligt at beskrive akademisk uden at blive draget ind i normative og juridiske diskussioner om sandheder og rettigheder på hver sin side af de facto-grensen. Lundgren adresserer kritisk både realpolitiske spørgsmål om internt fordrevnes politiserede status, deres konkrete udfordringer og potentielle tilbagevenden, og hun bidrager i særdeleshed til vores viden om grænser, grænseskabning og hjem som komplekse konfigurationer af både stedslige, tidslige, sociale, symbolske og strukturelle faktorer. Den væsentligste styrke i Boundaries of Displacement består på den vis i belysningen af de menneskelige, og i nogen grad politiske, konsekvenser af den kontinuerlige konstruktion og afgrænsning af Abkhasien som hjemland både imellem myte og realitet, imellem offentlige diskurser og personlig erfaring og imellem fortid, nutid og fremtid. 